\section{A warm welcome}

\section{Scientists should embrace a move by evangelicals to join the debate on climate change.}

D resident George W. Bush likes to talk about his faith at every opportunity; then he jokes about the poor grades he received in science class. Bush, a methodist, experienced his shift towards religion late in life. But now he may find the ghosts of his long-lost science education rising up to meet him on Sunday mornings.

Bush identifies with the hazily defined but devout group of Americans known as evangelicals, who also form the bedrock of his electoral support. Loosely speaking, these are people who believe in the authoritative word of the Bible above all else. But now, it seems, the word of science textbooks may be gaining some authority of its own among the evangelicals.

Scientists should welcome the recent move by leading evangelicals to call for action on climate change (see page 136). Their statement provides an unprecedented opportunity for science to make a real impact on a broad segment of US society.

Americans as a whole are deeply devout, a fact that has perplexed environmental groups that operate from an agnostic or atheist perspective. But the disconnect is not just about religion. Talk to people in America's heartland and you will find an underlying distrust of academics from either coast. Any indication that there might be a problem with the climate - and that pick-up trucks might have something to do with it - is likely to be viewed with hostility or suspicion. This is a culture in which people like to do things their own way, and they resent mandates that they perceive as being handed down by city-based élites.

Evangelicals themselves feel alienated from much of the country; one 2004 poll showed that $48 \%$ of evangelicals feel they are looked down on by most of their fellow Americans. Scientists should take the opportunity to reach out to this group.

The United States is unlikely to sign up to any successor agreement to the Kyoto treaty to cut greenhouse-gas emissions without a groundswell of support from its citizens. The evangelical leaders' open approach to the issue is a clear signal that it's okay to be religious, devout even, and still believe that climate change is a major problem.

With a blessing from religious leaders, Americans no longer need to feel divided between

\section{'The evangelical leaders' approach is a clear signal that it's okay to be religious, devout even, and still believe that climate change is a major problem."} their conservative beliefs and their concern for the planet. The evangelicals' call to action draws on a long history of Christian environmental activism, founded on the notion of caring for Earth as a gift from God, to be cherished for future generations. But in this case it confronts one of the most politically charged issues of the day.

The evangelicals' declared interest in the climate-change issue is an important approach that climate scientists should welcome with open arms. The scientists should engage with them at every possible level, starting at their local church. Perhaps, in due course, even President Bush will become part of the discussion.

\section{Slow train coming}

\section{Reform of Ukraine's archaic research system is needed sooner rather than later.}

$\bigcup$ kraine suffers from an identity crisis that is inhibiting its scientific, as well as its economic and political, development. The 48 million inhabitants of the former Soviet republic are deeply divided between pro-European and pro-Russian factions. The celebrated 'orange revolution' of November 2004 did less to bridge this divide than is commonly thought.

The nation's research system broadly reflects this wider societal divide. On the one hand, there are many young, well-educated and highly motivated researchers and a network of increasingly independent universities. On the other, there's the National Academy of Sciences of Ukraine, a leviathan of militant senility that retains just enough power to control critical aspects of Ukraine's scientific life.

The academy employs 45,000 permanent staff in a network of largely unproductive research establishments. Given the advanced age of its senior management, time alone will eventually resolve the issue. But that won't happen soon enough for those young Ukrainians currently in search of a productive scientific career.

Integrating the Ukraine into the Framework research programme of the European Union (EU) would allow this generation far greater interaction with its peers abroad. The European Commission supports the idea, which could also help open the way to future EU membership for Ukraine. But the leadership of the academy, deeply rooted in Soviet traditions, seems to be thwarting such integration through a mixture of contrariness and lack of interest (see page 132).

A high-level EU-Ukrainian steering committee on scientific cooperation, for example, was established on paper four years ago but has yet to actually meet. When it does, the academy's leaders are expected to obstruct collaborative steps that might bring an infusion of foreign influences into the country-including respect for the value of independent peer review.

Ukrainian science has potential in several spheres, including materials sciences, radioastron-
"The nation badly needs to focus its scarce resources in those areas where its scientists can compete." omy, theoretical physics and agricultural research. The nation badly needs to focus its scarce resources in those areas where its scientists can compete, and dispose of some of its anachronistic scientific heritage. That will require a rigorous external evaluation of the performance of hundreds of the academy's institutes.

The government needs to identify these reforms as a priority and then act with determination to overcome the academy's likely resistance to them. The oligarchy that has controlled Ukrainian science since Soviet times may then lose out. But the nation's economic potential and its prospects for integration into the $\mathrm{EU}$, as well as science itself, can only benefit. 